\title{
canódromo madrileño
}

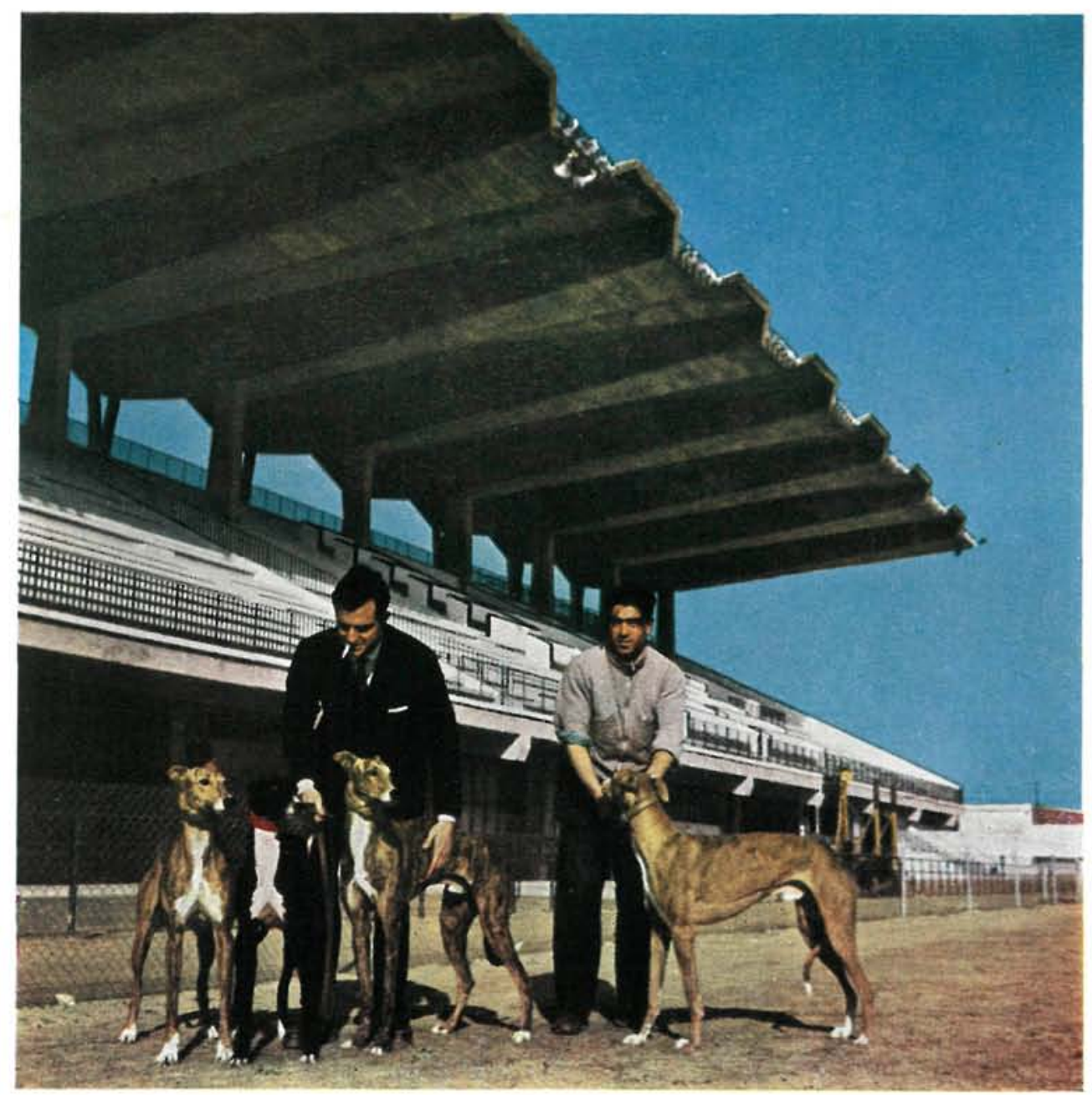

\author{
arquitectos: JOSE RAMON AZPIAZU \\ PEDRO PINTO \\ ingenieros: \\ JOSE ANTONIO TORROJA \\ FLORENCIO DEL POZO \\ RAFAEL LOPEZ PALANCO
}

aparejador:

J. L. MARTIN TORDESILLAS

$154-5$

S I N O P S I S

La importancia constructiva y estructural de esta obra, cuyo voladizo de tribunas constituye una de las mayores realizaciones resueltas en estructura laminar, son debidamente estudiadas en su triple aspecto de: proyecto, construcción y cálculo. 

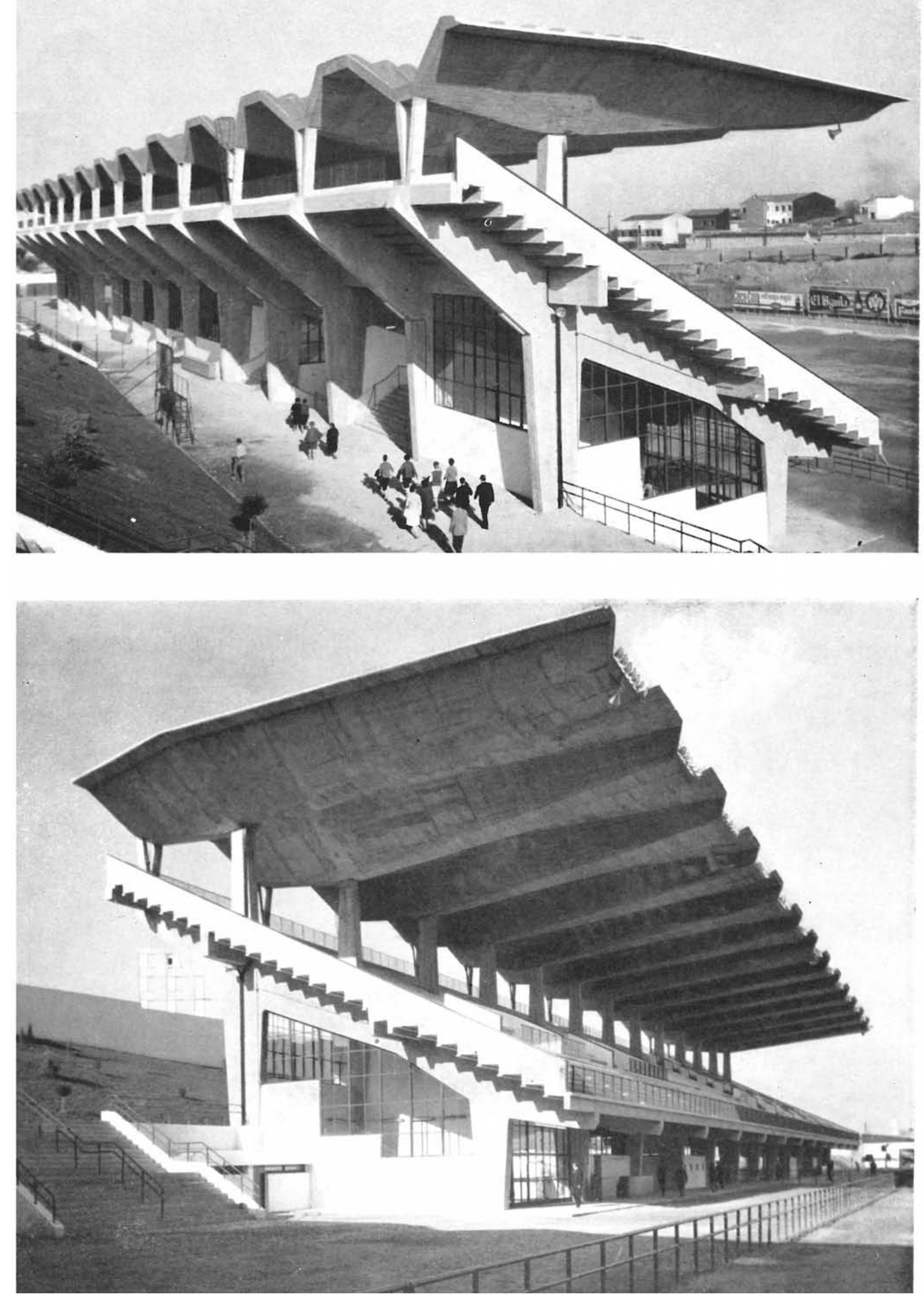


\section{Sifuación}

La capital de España carecía de una instalación de canódromo digna de su capitalidad. Constituída la Sociedad «Canódromo Madrileño, S. A.», y gracias a la eficiente actividad desarrollada por la misma, pronto se ha convertido en realidad la aspiración de crear unas instalaciones adecuadas a las exigencias de esta actividad deportiva.

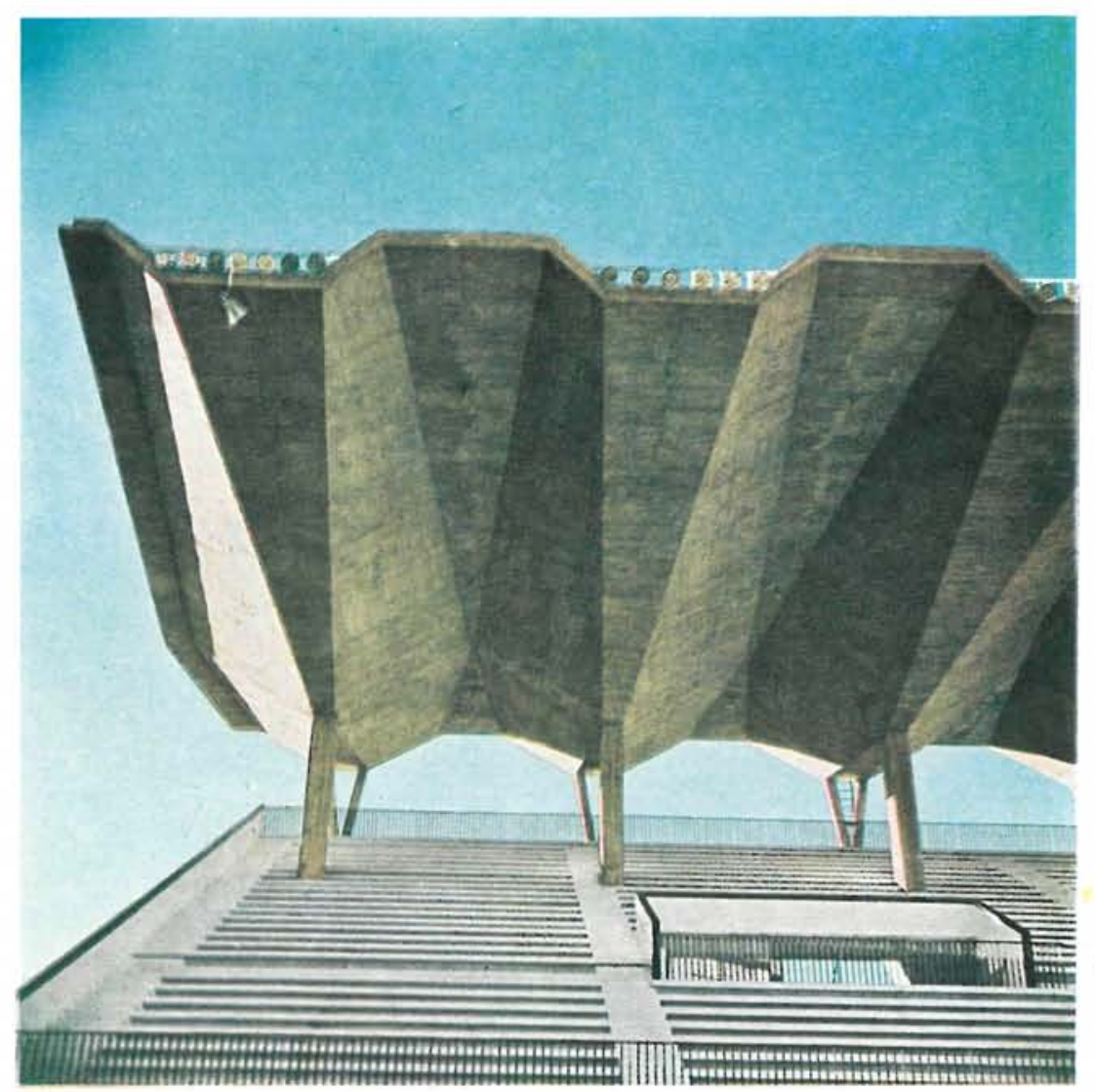

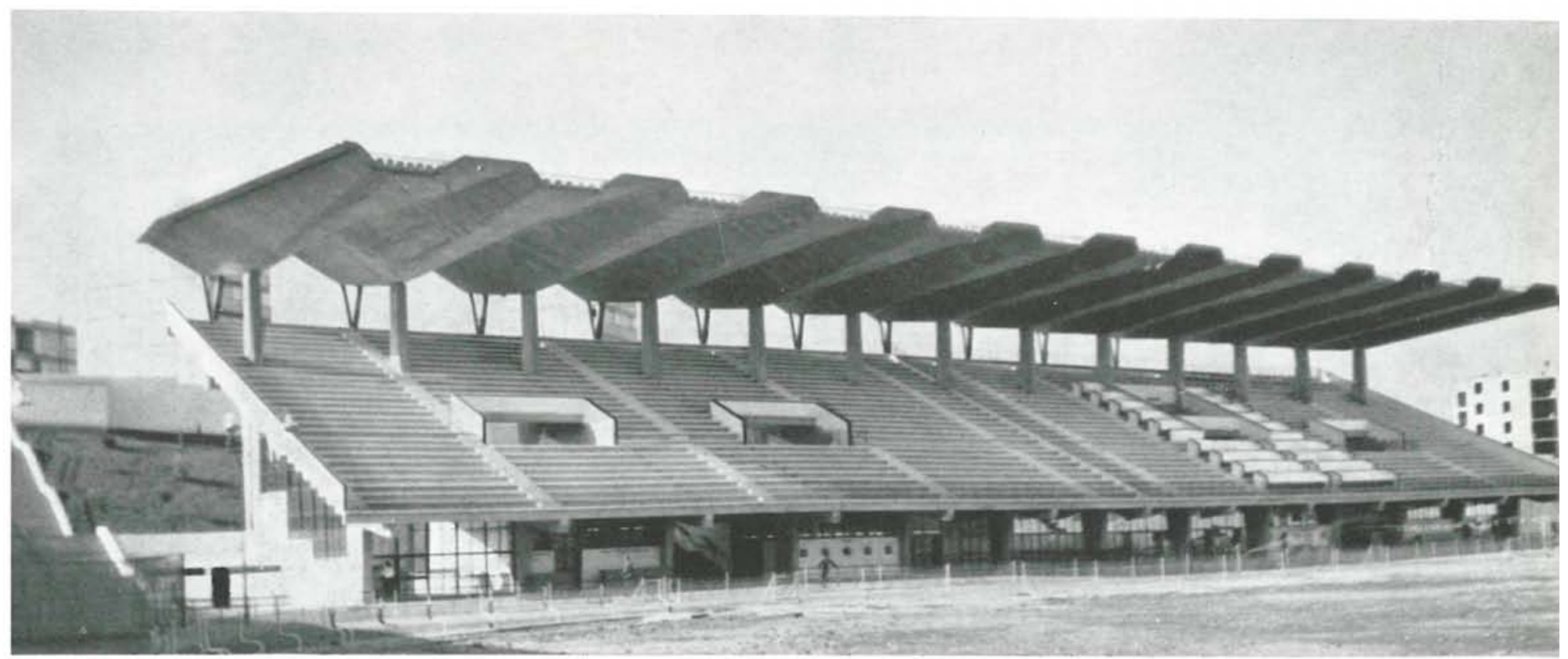

vistas y detalle de la tribuna 


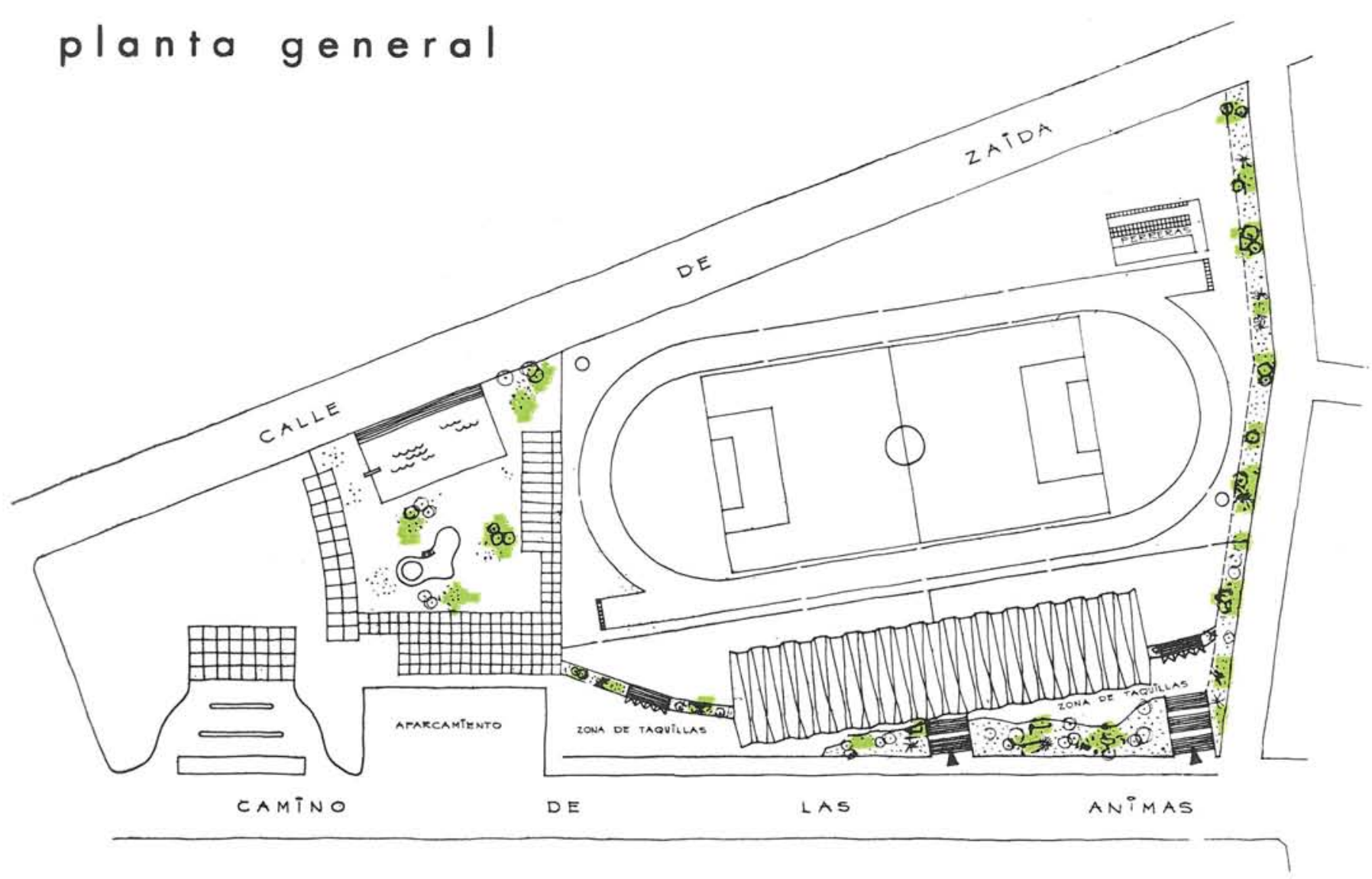

El solar elegido, situado en Carabanchel Bajo, al oeste de la Sacramental de San Isidro, pertenecía antiguamente a una industria cerámica, que había ido excavando poco a poco el solar hasta alcanzar desniveles de $12 \mathrm{~m}$ de altura.

La vía de acceso más importante es la calle Camino de las Animas, abierta a la circulación recientemente, que enlaza el Camino Alto de San Isidro con Carabanchel Bajo.

\section{Programa}

Un canódromo constituye un tema especializado en el que, además de los problemas comunes de toda instalación deportiva, referentes a tribunas y dependencias para el público, existen los propios de su especialidad, que, a la vez, son dobles, dada la doble actividad de carreras y apuestas.

El programa se puede concretar en: un amplio hall de apuestas, dotado de las correspondientes taquillas de venta de boletos, independientes de las de pagos de premios y de una pizarra en la que se señalan, en cada carrera, el número total de boletos vendidos, resultados y combinaciones de ganadores y colocados; zona de jueces de salida y de jueces, comisarios y cronometradores de llegada, en contacto directo con el director de carreras y con los micrófonos y laboratorio fotográfico; perreras, debidamente separadas del público, donde tres horas antes de la carrera se pesan y reconocen los perros, por el veterinario, y se precinta la puerta para evitar el drogado; enlace totalmente independiente de las perre- 

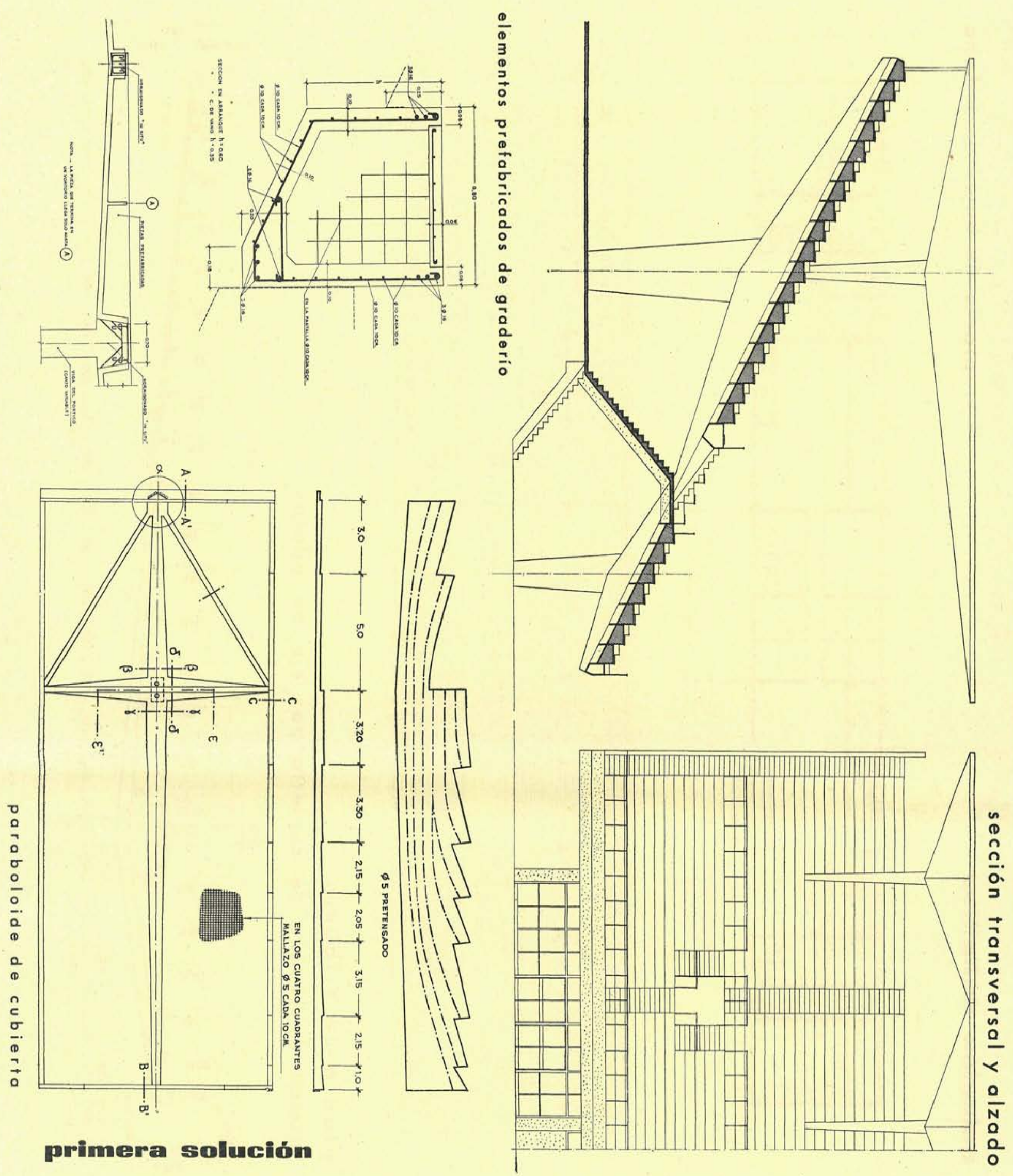
0
5
0
0
2
5
0
0
0
0
0
0
0
0
0
$\frac{0}{5}$
0
$\frac{0}{2}$
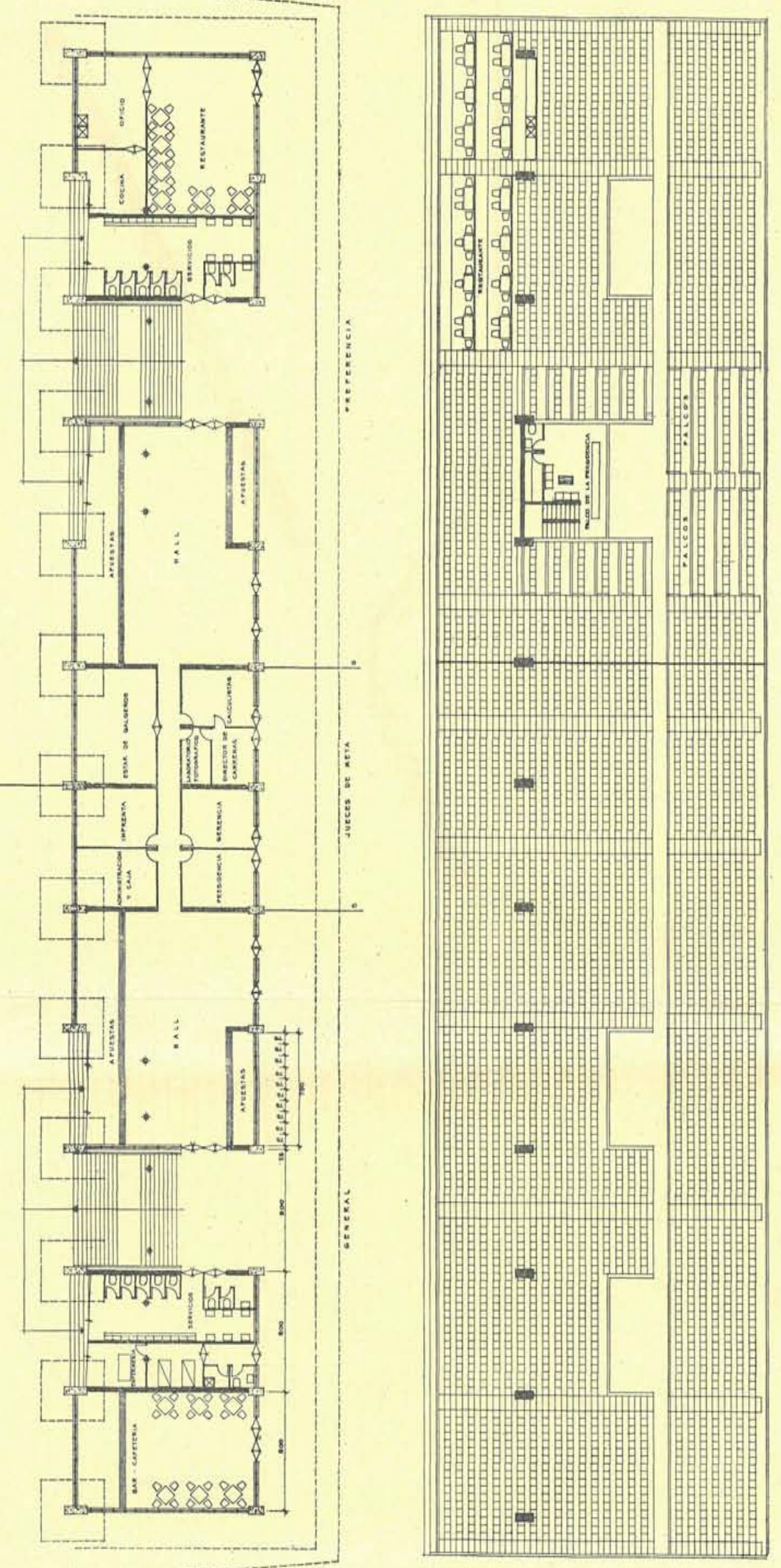

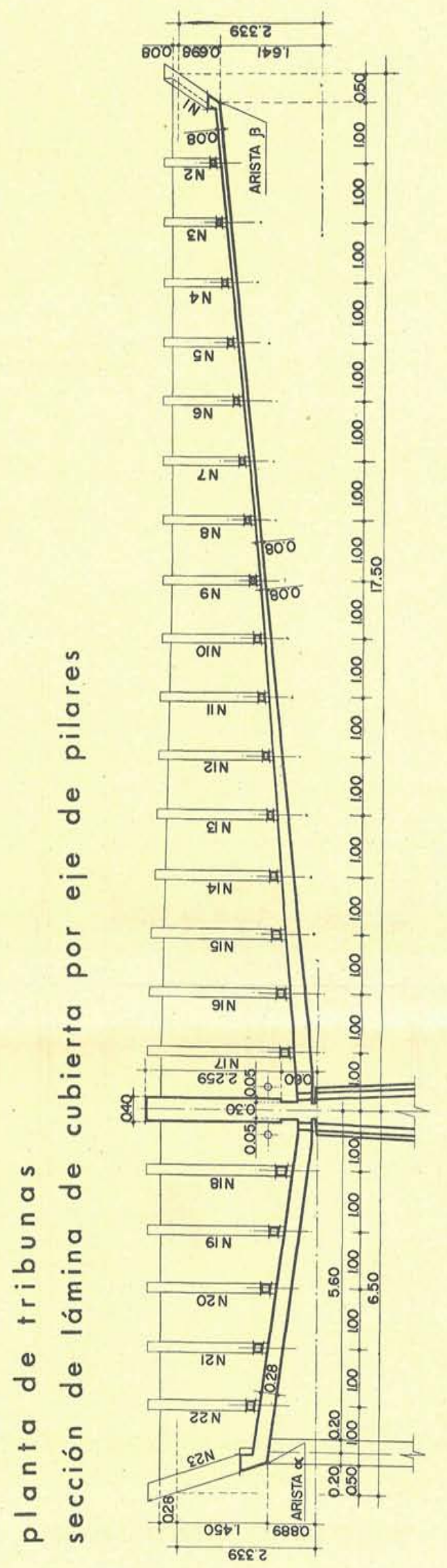




\section{sección transversal de tribunas}

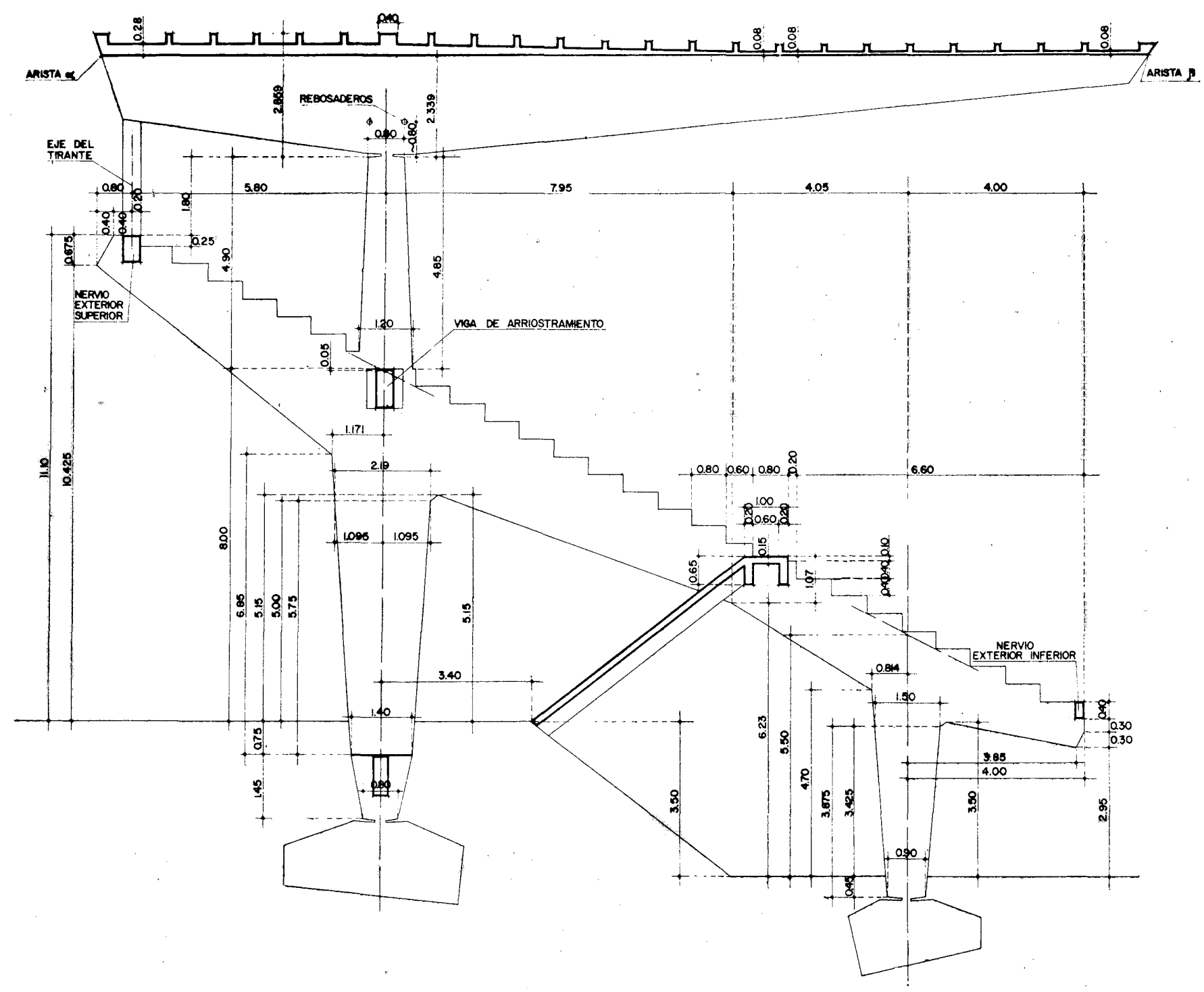

pórticotipo

ras con el paseo de pista, donde se exhiben los galgos antes de la carrera; liebre mecánica, formada por pieza disecada y montada sobre trineo, tirada por cuerda que se desliza alrededor de las poleas que existen en el bordillo interior de la pista y movida por motor eléctrico; tribunas para el público, debidamenie enlazadas, con el hall de apuestas, restaurante, bar y servicios. 

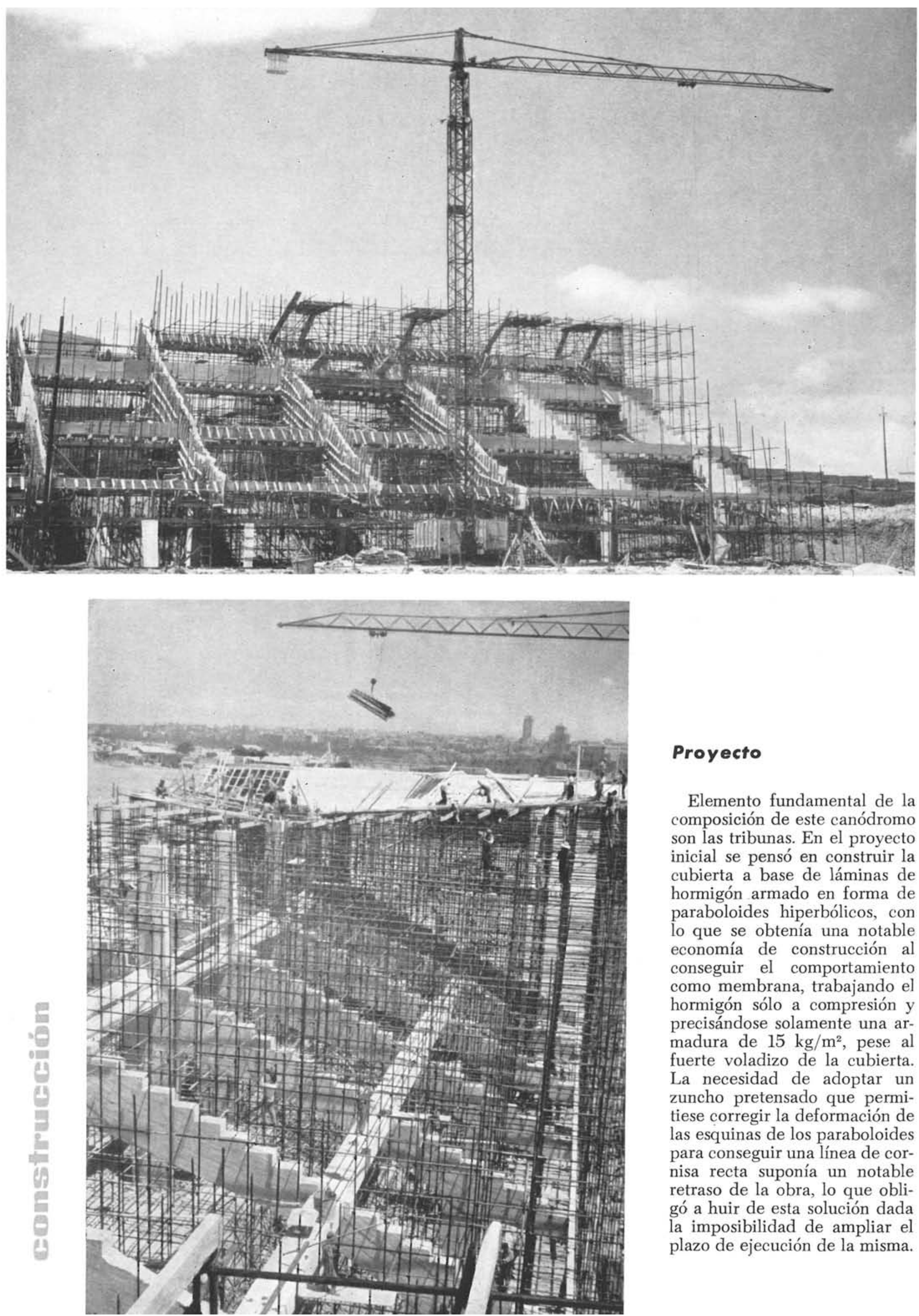

\section{Proyecto}

Elemento fundamental de la composición de este canódromo son las tribunas. En el proyecto inicial se pensó en construir la cubierta a base de láminas de hormigón armado en forma de paraboloides hiperbólicos, con lo que se obtenía una notable economía de construcción al conseguir el comportamiento como membrana, trabajando el hormigón sólo a compresión y precisándose solamente una armadura de $15 \mathrm{~kg} / \mathrm{m}^{2}$, pese al fuerte voladizo de la cubierta. La necesidad de adoptar un zuncho pretensado que permitiese corregir la deformación de las esquinas de los paraboloides para conseguir una línea de cornisa recta suponía un notable retraso de la obra, lo que obligó a huir de esta solución dada la imposibilidad de ampliar el plazo de ejecución de la misma. 


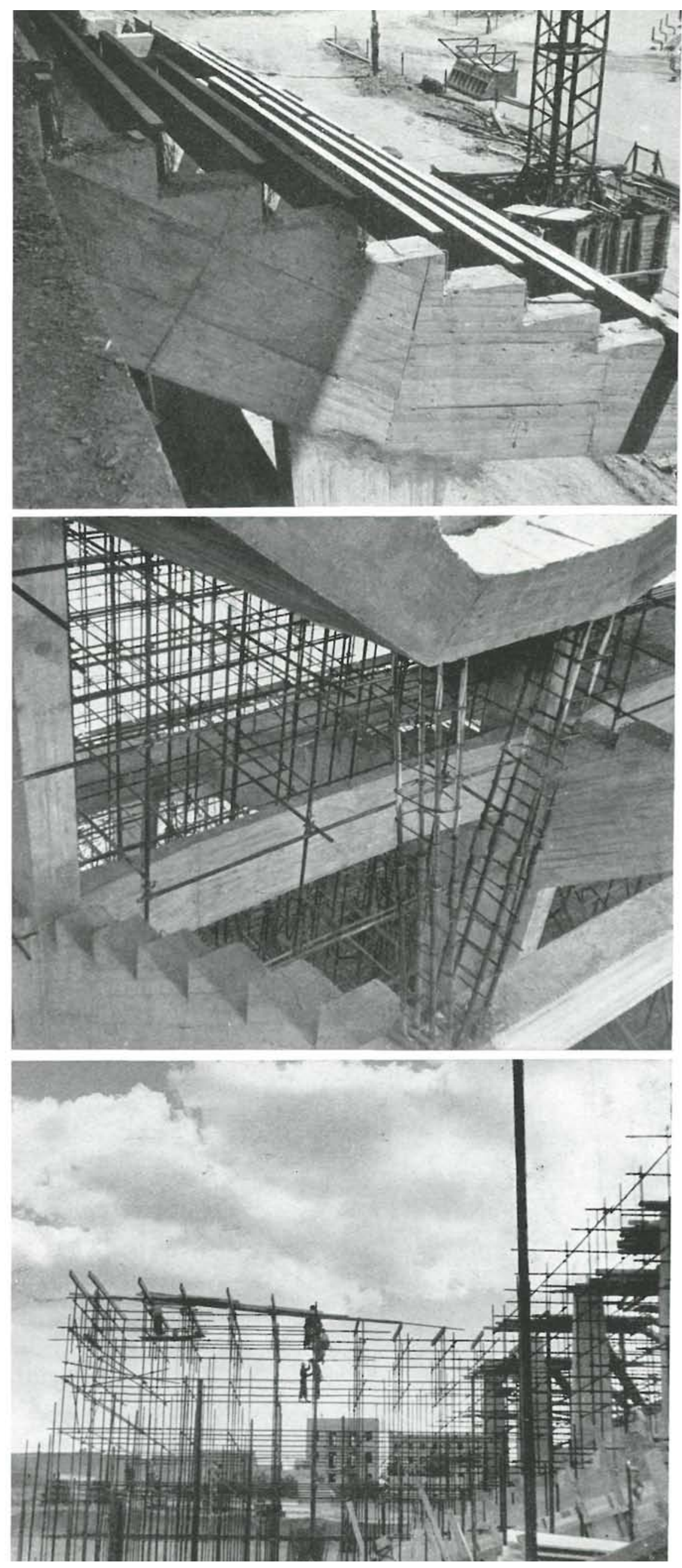

También en el proyecto inicial se pensó en construir el graderío mediante vigas cajón de hormigón armado que, debidamente ancladas en los pórticos transversales, salvaban las luces de vanos definiendo el graderío. El excesivo peso de cada uno de estos elementos forzó también a cambiar la so. lución inicial.

\section{Solución definitiva}

La cubierta está definida por una lámina plegada de hormigón armado, con nervios superiores de rigidización, y apoyada articuladamente sobre un pilar y posteriormente anclada mediante tirantes en V. En esta solución la lámina trabaja en régimen de flexiones, exigiendo la colocación de una armadura media de $33 \mathrm{~kg} / \mathrm{m}^{2}$.

El graderío está definido por viguetas prefabricadas de hormigón pretensado en las tabicas y placas, también de hormigón, en las huellas sobre las que corren los asientos.

La tribuna cubierta tiene una capacidad para 5.000 espectadores, y bajo la estructura del graderío se distribuyen los hall de apuestas, bares, servicios, oficinas, etc. En el extremo norte se ha instalado un restaurante que comunica con el situado bajo la tribuna por medio de montaplatos.

Construído inicialmente el ca. nódromo, de primera categoría, se ha proyectado la ampliación de sus instalaciones deportivas mediante la construcción de dos piscinas con sus vestuarios correspondientes; un restaurante ligado a las mismas, una bolera cubierta y las oficinas generales 


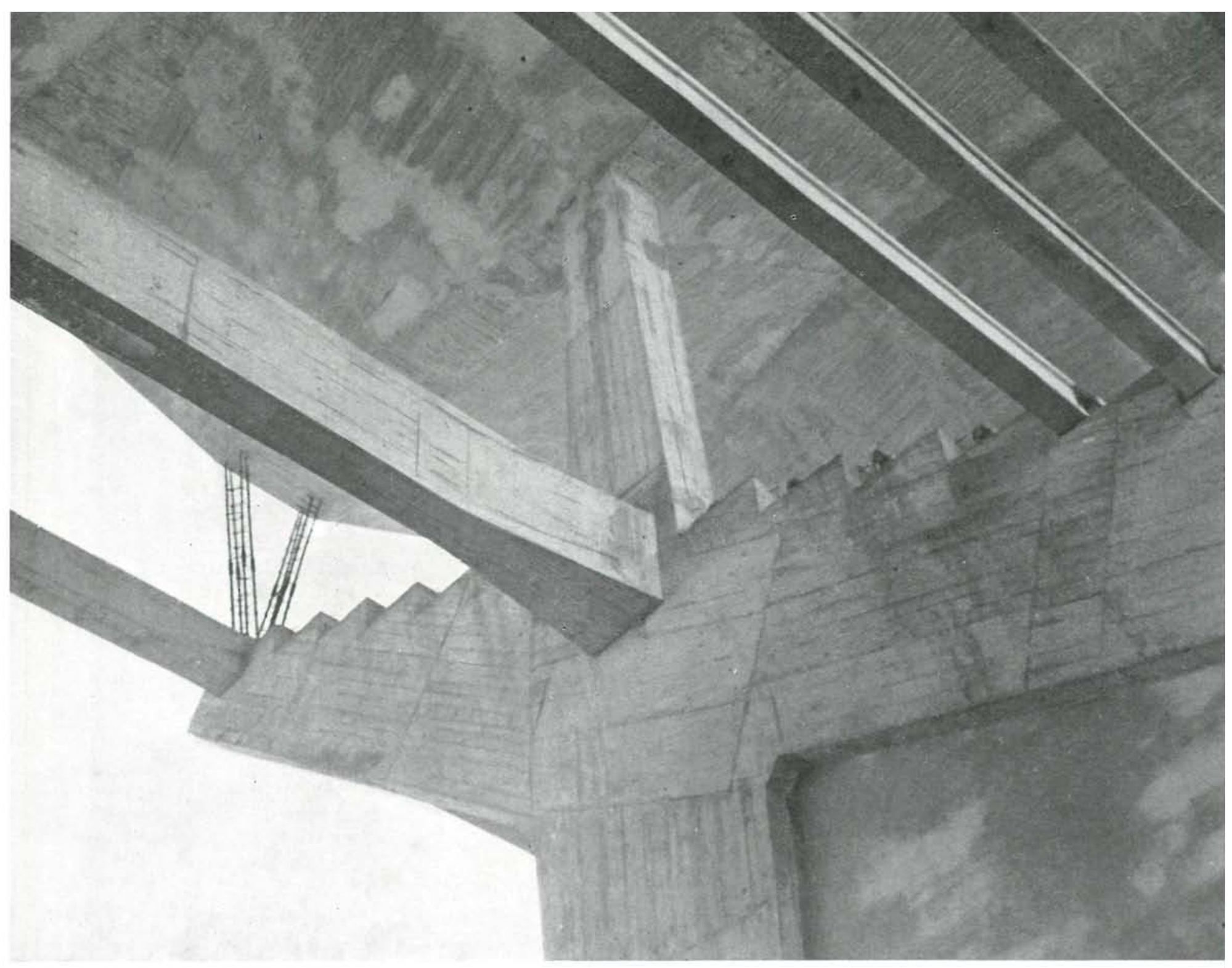

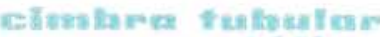
moset ailices

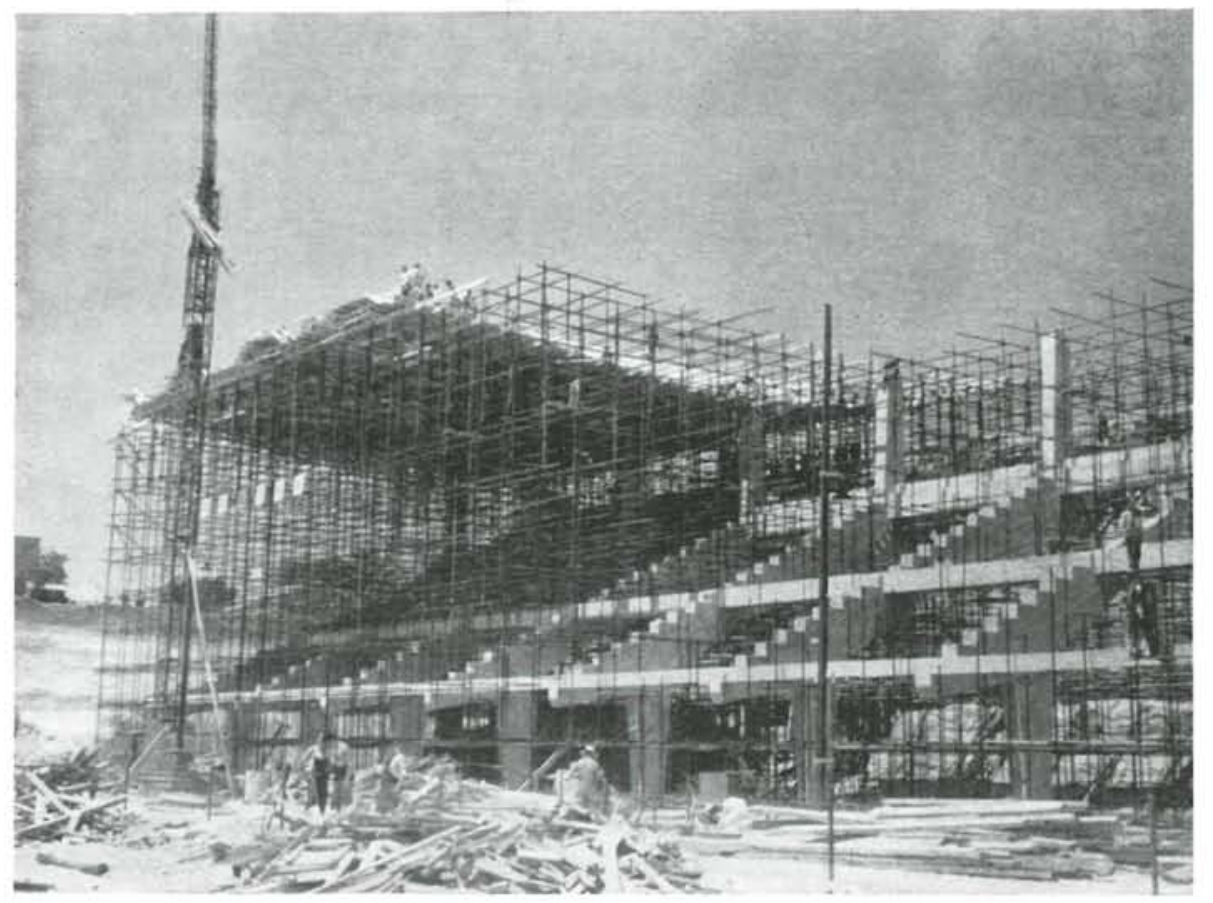


de la Sociedad. Asimismo, en la esquina, en donde se ha proyectado una futura plaza, se ha previsto la construcción de una estación de gasolina.

\section{Construcción}

La necesidad de construir toda la tribuna en una sola fase, debido a la premura de tiempo, obligó a emplear gran número de encofrados y una complicada estructura tubular metálica como cimbra de apoyo de los mismos.

El hormigonado de la cubierta laminar se hizo por elementos, comenzando por el borde posterior y realizándose simultáneamente la lámina y sus nervios rigidizadores. Hormigonado el elemento horizontal, y vibrado su hormigón, al día siguiente se procedía a colocar el encofrado del tímpano, que se hormigonaba dos días más tarde.

Se desencofró, primeramente, la zona comprendida entre la línea de apoyos y tirantes, tensándose éstos, a continuación, operación que se hizo simultáneamente en todos ellos. El desencofrado de la parte elevada se realizó al mismo tiempo en toda su longitud, con obieto de evitar tensiones producidas por el descenso parcial de las partes desencofradas. La flecha apropiada en el borde volado fue de 5 centímetros.
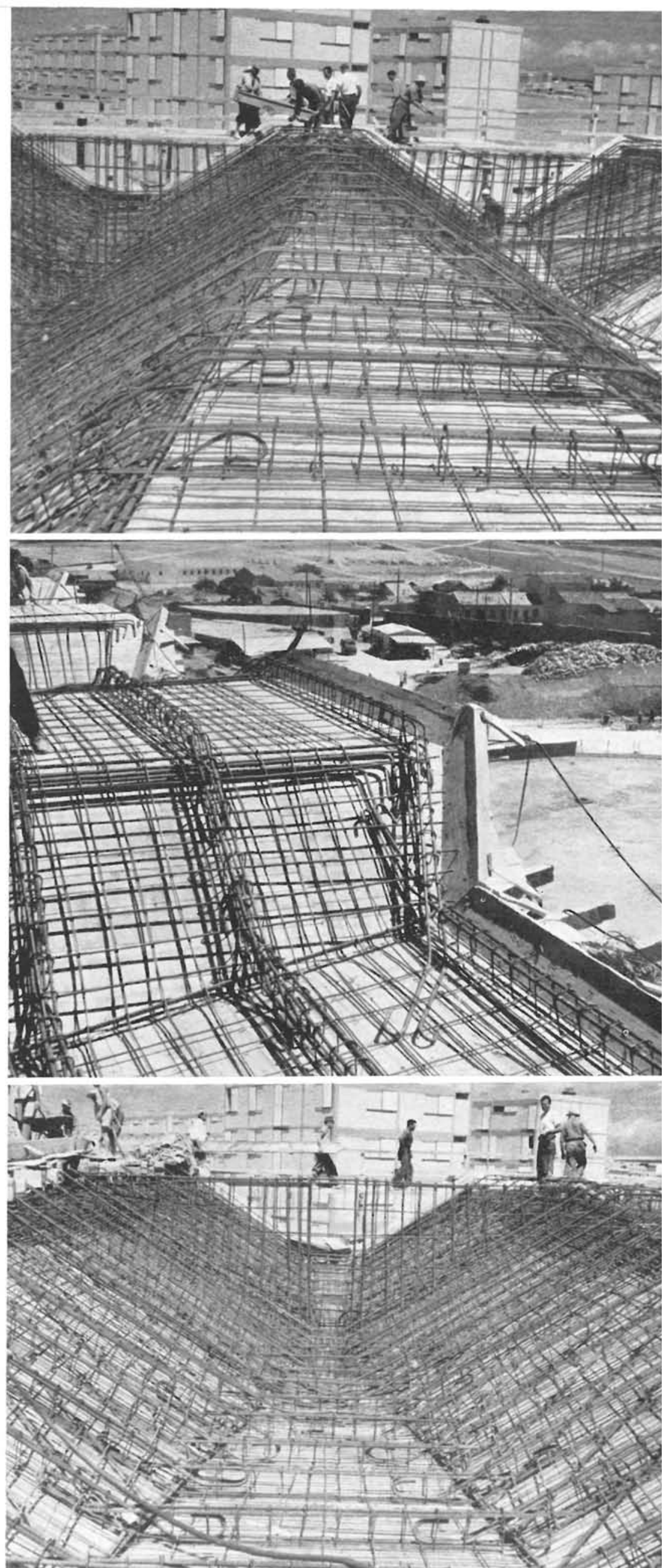


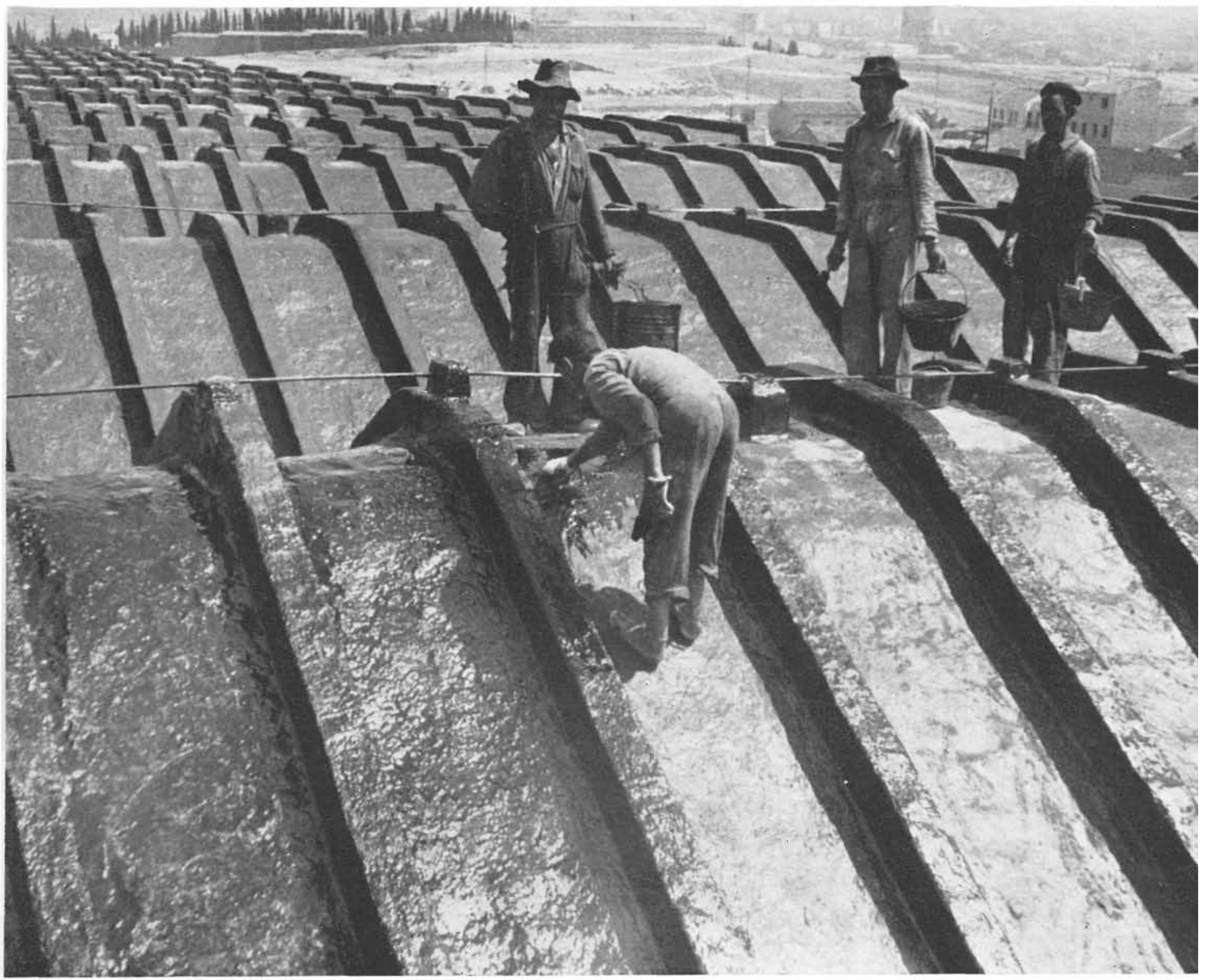

\section{Cálculo}

Para comprobar los resultados del cálculo de las láminas que constituyen la cubierta de las tribunas del Canódromo, se recurrió al ensayo, sobre modelo reducido, en el Laboratorio Central de Ensayo de Materiales de Construcción, de Madrid.

El modelo, a escala $1: 25$ se construyó con planchas de plexiglás de tres espesores diferentes-4, 8 y $10 \mathrm{~mm}$ - con el fin de seguir, lo más de cerca posible, las variaciones de espesor de la lámina real. Las planchas están soldadas unas a otras con pegamento especial, y se aseguraron contra posibles deslizamientos por despegue con pequeños cilindros de plexiglás de $3 \mathrm{~mm}$ de diámetro que atravesaban las juntas entre dos planchas contiguas.

El modelo se colocó sobre una estructura de acero, contra la cual se tensaron los tirantes posteriores, representados por redondos de acero de $4 \mathrm{~mm}$ de diámetro. 

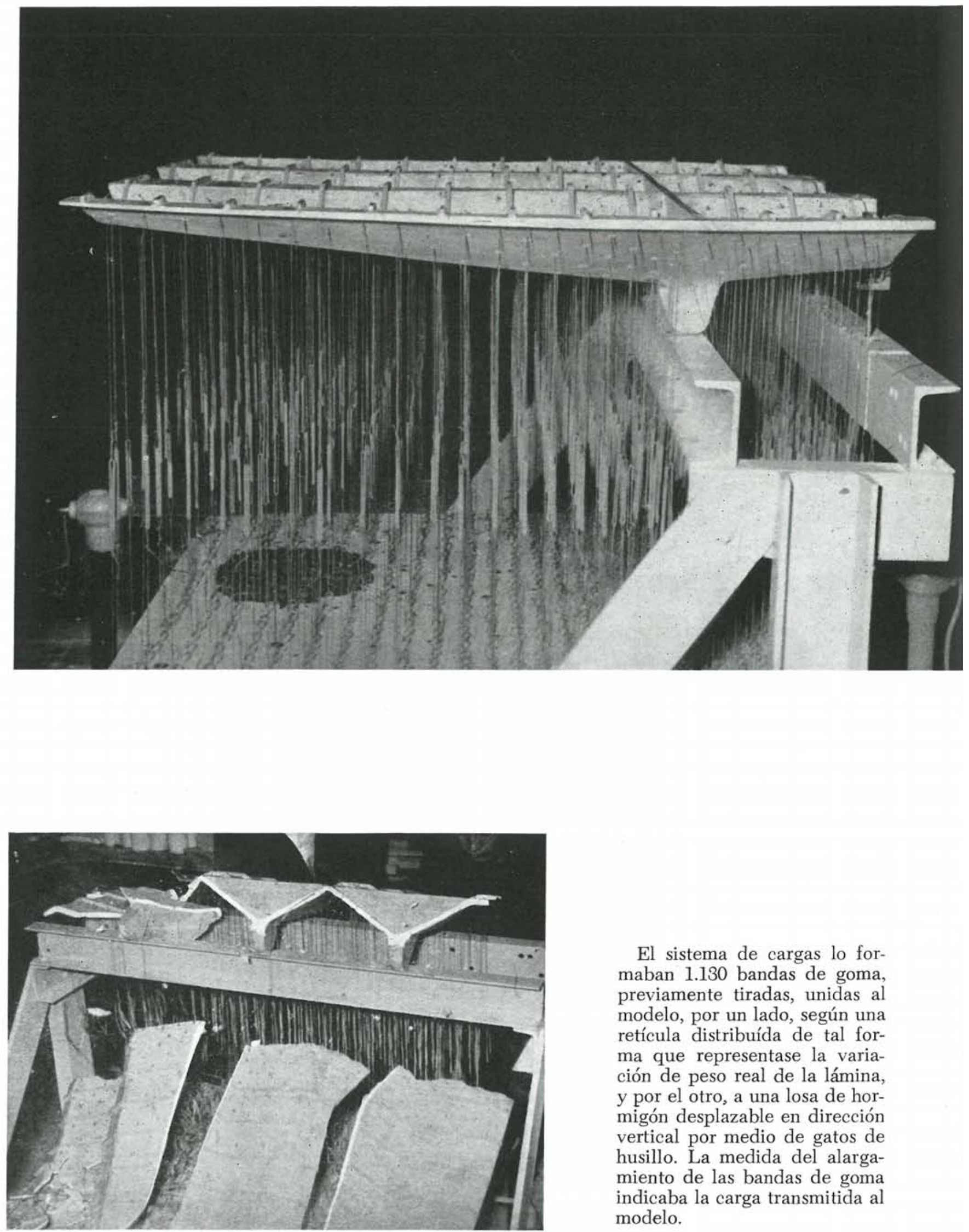

El sistema de cargas lo formaban 1.130 bandas de goma, previamente tiradas, unidas al modelo, por un lado, según una retícula distribuída de tal forma que representase la variación de peso real de la lámina, y por el otro, a una losa de hormigón desplazable en dirección vertical por medio de gatos de husillo. La medida del alargamiento de las bandas de goma indicaba la carga transmitida al modelo. 
La obtención de los momentos transversales se efectuó mediante la medición de las variaciones de curvatura con un curvímetro de gran precisión.

Para la medida de los recorridos, tanto en dirección vertical como horizontal, se utilizó un procedimiento fotográfico, que consiste en impresionar, sobre el mismo negativo, las imágenes del modelo, antes y después del proceso de carga, sirviéndose de distintos testigos, unos situados sobre el modelo $\mathrm{y}$ otros independientes de éste.

Con objeto de completar estos ensayos elásticos determinados sobre el modelo de plexiglás, se construyeron dos modelos de escayola, que se ensayaron en rotura.

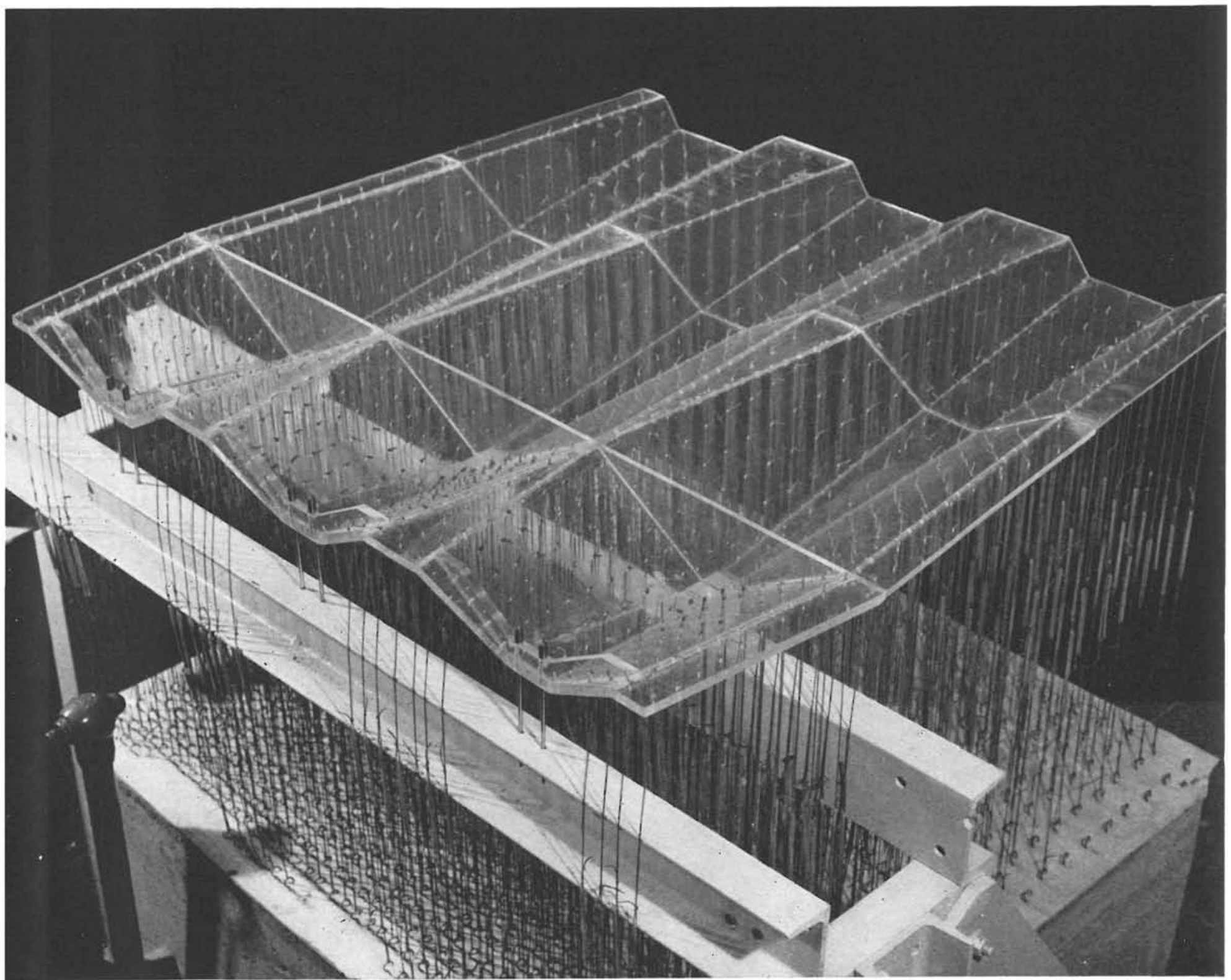



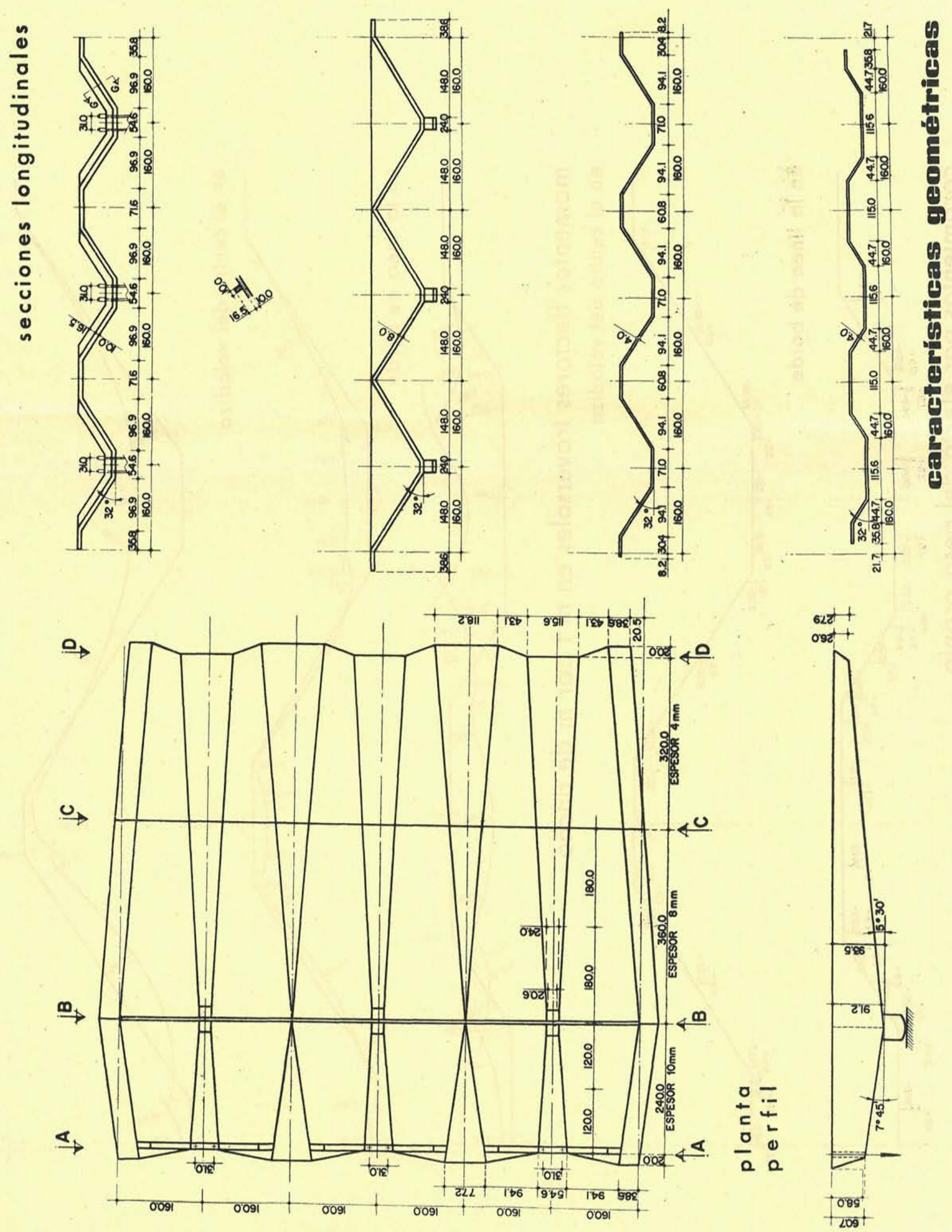


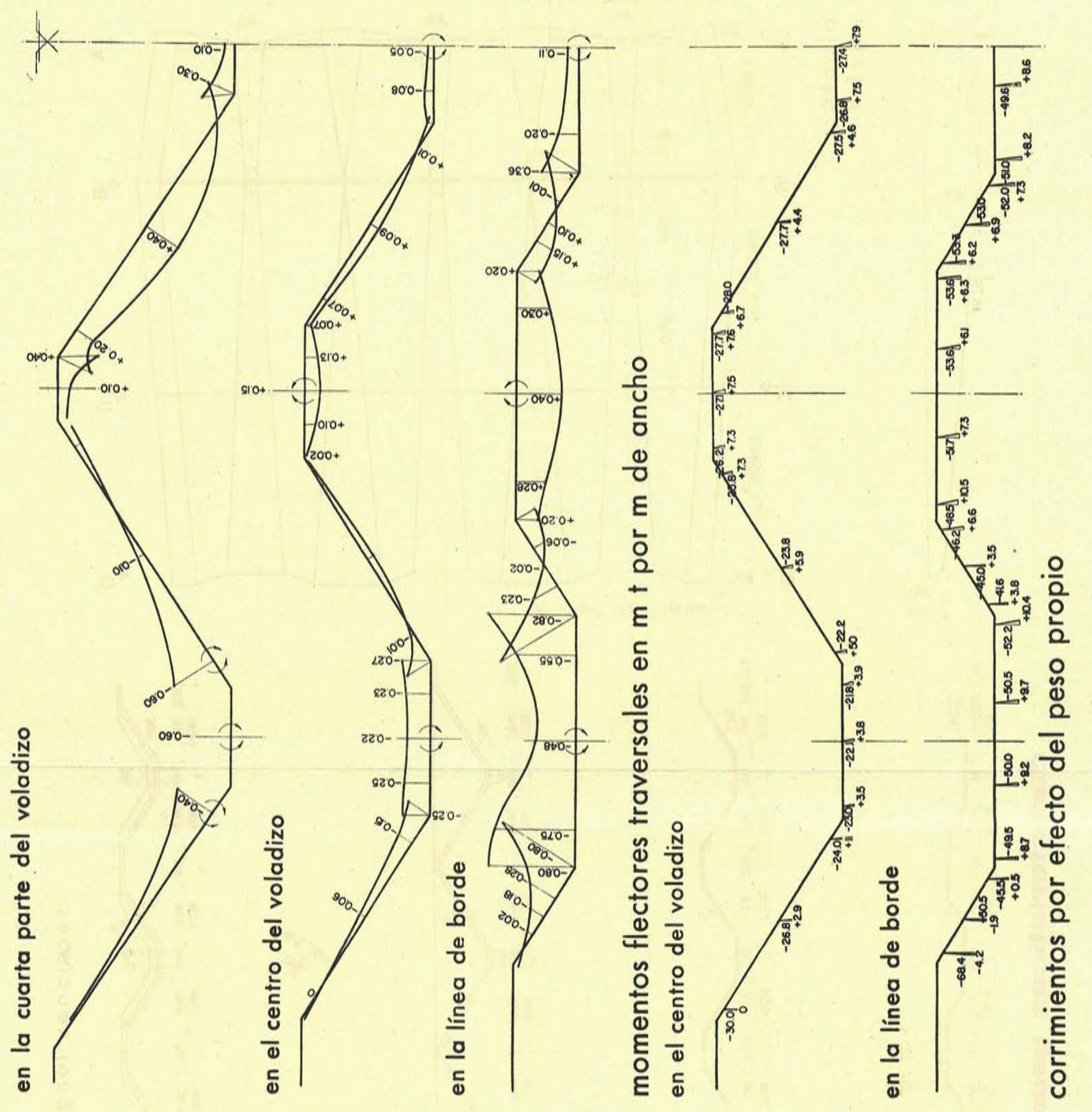




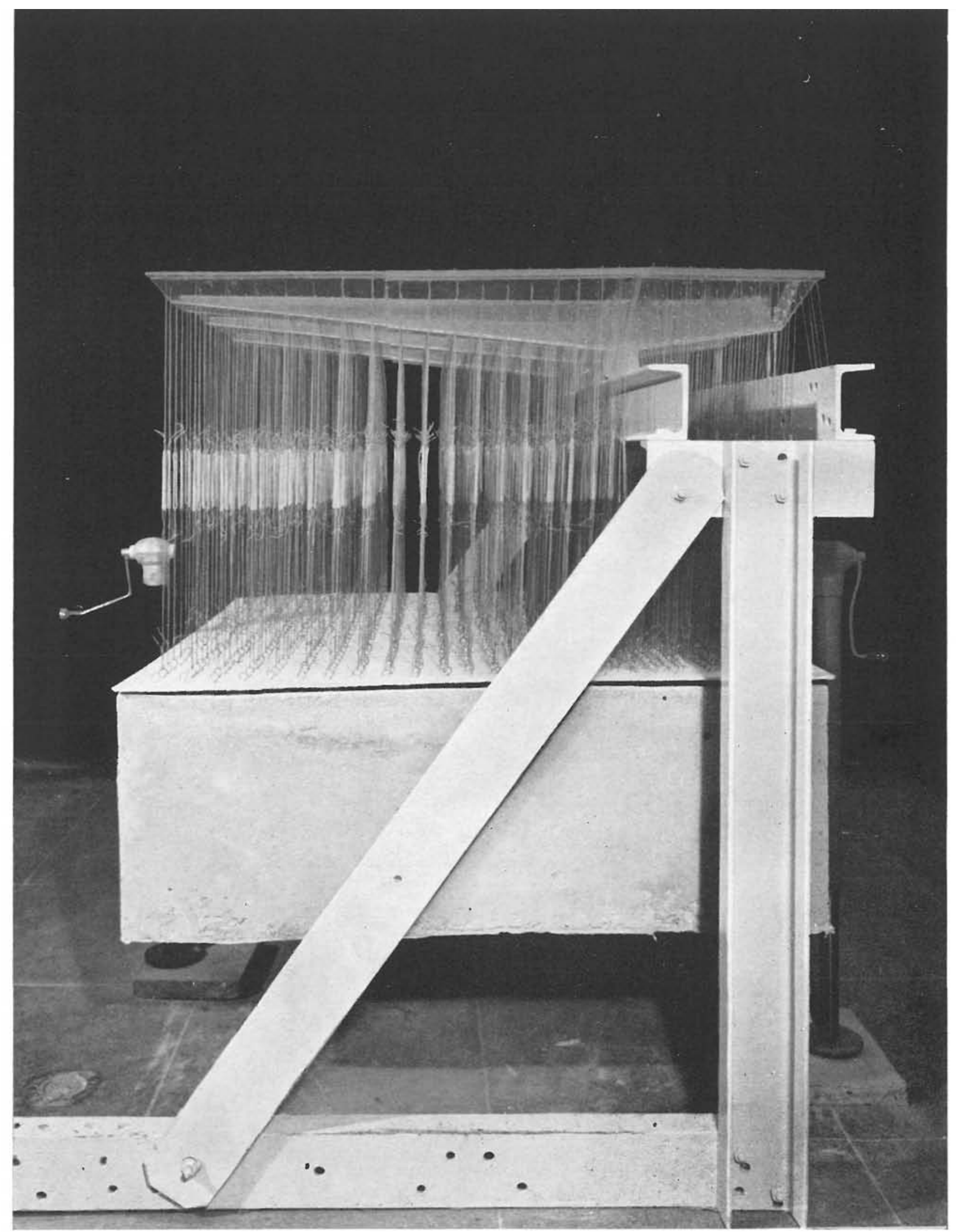

\section{Conclusión}

La unidad del conjunto se basa en la sinceridad constructiva, dejando que cada material luzca su propia textura, y haciendo que los paramentos de hormigón armado, a cara vista, acusen la huella de su encofrado y dominen por su prodigalidad y audacia estructural. 

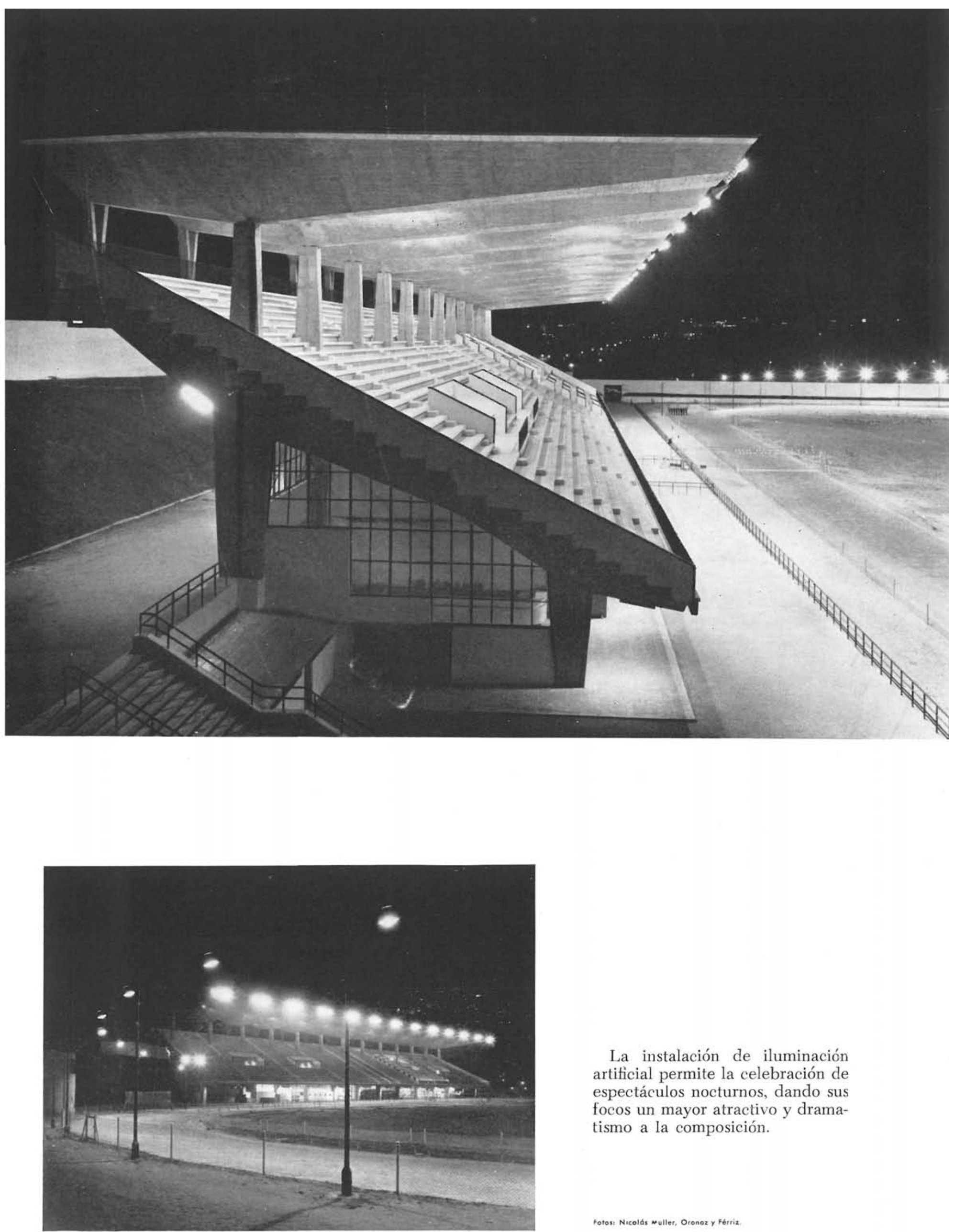

La instalación de iluminación artificial permite la celebración de espectáculos nocturnos, dando sus focos un mayor atractivo y dramatismo a la composición. 